Support for Lesbian and Gay Rights:

How and Why the South Differs From the Rest of the Country

\author{
Gregory B. Lewis and Reynold V. Galope
}

The South provides far fewer legal protections for lesbian, gay, bisexual, and transgender Americans than does the rest of the country. Because state gay rights policies strongly reflect public opinion, trends in and the causes of Southerners' stronger opposition to homosexuality and gay rights are key to the future of lesbian and gay rights in the region. Using data for over 200,000 respondents to over 150 surveys, we assess the width, stability, and roots of Southern differences in beliefs about whether homosexual sex should be legal, schools should employ lesbian and gay teachers, same-sex marriage should be legal, and homosexual relations are "not wrong at all." We find strong and stable regional divergences that owe much to Southerners' greater religiosity, conervatism, and Republican party identification and their higher probabilities of being evangelical Protestants and African Americans. Migration patterns seem to maintain rather than to narrow or widen regional differences on gay rights.

In 2011, 21 states and the District of Columbia banned employment discrimination on the basis of sexual orientation; none of them was in the South (National Gay and Lesbian Task Force 2011). When the U.S. Supreme Court ruled that sodomy laws were unconstitutional (Lawrence $v$. Texas 2003), 14 states still outlawed homosexual sex; nine of them were in the South. Six states and the District of Columbia now provide full marriage equality, another eight provide broad relationship recognition, five provide limited relationship recognition, and four states that do not issue marriage licenses to same-sex couples recognize marriages performed in other states; no Southern state grants any legal recognition to same-sex couples (National Gay and Lesbian Task Force 2011). All 15 Southern states prohibit same-sex marriage (SSM) by law, 12 of them also have constitutional bans, and 9 of those amendments also ban other forms of same-sex partner recognition (National Gay and Lesbian Task Force 2009).

Popular opposition to lesbian and gay rights in the South explains much of this regional divergence, as state policies strongly reflect public opinion on this issue (Lax and Phillips 2009; Lewis 2003; Lewis and Oh 2008). Lewis $(1999,2001)$ finds that 12 of the 15 states that most strongly favored criminalization of homosexual sex in 1996 and 12 of the 15 states that most

GREGORY B. LEWIS is Professor and Chair of Public Management and Policy in the Andrew Young School of Policy Studies at Georgia State University, Atlanta, Georgia. REYNOLD V. GALOPE was a Ph.D. student in Public Policy and Fulbright Fellow at Georgia State University and Georgia Institute of Technology, Atlanta, Georgia; he is currently Senior Fellow of the Development Academy of the Philippines.

The American Review of Politics, Vol. 34, Winter, 2013-2014: 271-297

(C2013 The American Review of Politics 
opposed hiring lesbian and gay teachers in 1998 were in the South. Lewis and $\mathrm{Oh}(2008,47)$ find that 11 of the 12 states that most strongly opposed SSM in 2006 were in the South, that the most supportive Southern state (Florida) ranked 25th nationally, and that across all 15 Southern states only about 22 percent supported SSM. Similarly, Lax and Phillips $(2009,48)$ find that 10 of the 14 states with the least support for SSM in 2008-2009 were in the South, that mean support across the 15 Southern states was only 28 percent, and that support was rising more slowly in the region than in the rest of the country.

This paper assesses the width, stability, and roots of Southern differences from the rest of the country in support for gay rights. Using data for 40,000 respondents to 32 surveys on whether homosexual sex should be legal; 44,000 respondents to 33 surveys on employment of homosexual teachers; 126,000 respondents to 100 national surveys on SSM; and 29,000 responses on the wrongness of homosexual relations in 22 years of the General Social Survey (GSS); we first show that Southerners are substantially less likely than other Americans to support lesbian and gay rights and to accept homosexuality and that this regional divergence has not narrowed in the past forty years. Using logit analysis on combined samples, we then demonstrate that the higher proportion of evangelical Protestants and African Americans in the South and Southerners' greater religiosity, conservatism, and Republican party identification all contribute to their greater opposition to lesbian and gay rights and condemnation of homosexuality. We also find that opposition to SSM among comparable individuals increases with the percentages of a state's population who are evangelical Protestants and political conservatives, and that the contextual effects of higher levels of evangelism in the South can account for the regional divergence that is not explained by individual characteristics. Finally, we show that migration patterns mostly maintain regional divergence: those with greater opposition to homosexuality are more likely to move into the South and those with higher levels of acceptance are more likely to move out.

\section{Background and Hypotheses}

In line with its history of greater intolerance across a variety of issues (Abrahamson and Carter 1986; Ellison and Musick 1993; Moore and Ovadia 2006; Valentino and Sears 2005), the South also has been a particularly inhospitable region for liberalization of gender roles (Carter and Borch 2005; Hurlbert 1989; Moore and Vanneman 2003) and acceptance of homosexuality and gay rights (Burdette et al. 2005; Lax and Phillips 2009; Lewis 1999, 2001; Lewis and Oh 2008). Southerners' increasing identification with the Republican Party appears largely due to its conservative racial attitudes 
(Valentino and Sears 2005). Evidence on whether regional differences are weakening or strengthening is mixed, with most of the evidence against polarization (Aistrup 2010; Carter and Borch 2005; Cook et al. 1993; DiMaggio et al. 1996; Evans 2003; Hurlbert 1989; Valentino and Sears 2005). The findings of Lax and Phillips (2009) suggest a widening regional divergence on SSM, but those of Lewis and Oh (2008) do not.

Explanations of Southern divergence include both compositional and contextual effects (Moore and Vanneman 2003). That is, the composition of the Southern population - the characteristics of the people who live thereshould predict greater opposition to SSM and lesbian and gay rights, but something about the Southern context should make apparently comparable individuals more likely to oppose gay rights if they live in the South than if they live elsewhere. In terms of composition, Southerners attend church more frequently; are more likely to be evangelical, conservative, Republican, and black; and tend to be less educated than other Americans. Religiosity, evangelism, conservatism, and Republican party identification are all associated with greater opposition to lesbian and gay rights (Brewer 2003; Haider-Markel and Joslyn 2008; Herek 1988; Lewis and Edwards 2011; Wilcox and Wolpert 2000). Although blacks have traditionally opposed antigay employment discrimination more than whites and were once no more likely to condemn homosexual sex, blacks' acceptance of homosexuality and support for lesbian and gay rights has increased more slowly than whites' over the past two decades (Boykin 1998; Chauncey 1995; Lewis 2003; Lewis and Gossett 2008). Acceptance generally rises with education (Grapes 2006; Ohlander et al. 2005). All these differences should contribute to regional divergence on homosexuality and on lesbian and gay rights, but their relative importance is not clear.

If opinion on SSM is polarizing regionally, compositional differences could be the explanation. Over the past two decades, support for SSM has increasingly polarized along partisan, ideological, and religious lines, with most of the increased support coming from Democrats, liberals, and the less religious (Lewis 2010; Lewis and Gossett 2008). Because the South is increasingly Republican and is more politically and religiously conservative than the rest of the country, both Southern opinion and law may lag behind the rest of the country for years to come. The liberalizing effects of cohort replacement-younger Americans support SSM at much higher levels than their elders do-seems to make increasing acceptance inevitable, however, even in the South (Lewis and Edwards 2011; Lewis and Gossett 2008).

Explanations of Southern intolerance generally argue for a "subcultural" explanation, since higher levels of prejudice and intolerance persist in the South after controlling for compositional effects (Abrahamson and Carter 1986; Middleton 1976; Nunn et al. 1978; Stouffer 1955; Tuch 1987). 
Protestant fundamentalism is one of the strongest predictors of intolerance, for instance, but Ellison and Musick (1993) find that Southerners remain substantially less tolerant than other Americans after controlling for their higher levels of fundamentalism, among other demographic characteristics. Moore and colleagues (Moore and Ovadia 2006; Moore and Vanneman 2003) argue that the effect of fundamentalism is contextual as well as compositional. Citing work by Books and Prysby (1988), Moore and Vanneman $(2003,119)$ argue that the strong presence of fundamentalists in a community can increase resistance to changing gender norms through "(1) social interaction with more like-minded others, (2) conformity to prevailing norms, and (3) information flow patterns." They find that the percentage fundamentalist in one's state or primary sampling unit has a strong effect on one's gender attitudes, even after controlling for a wide range of individual characteristics, including whether one is fundamentalist oneself. Indeed, Moore and Vanneman find that the fundamentalist context increases gender conservatism more for non-fundamentalists, though Moore and Ovadia conclude the opposite: that fundamentalist context has a stronger impact on the political tolerance of fundamentalists.

Migration patterns are generally expected to increase regional convergence. Interregional immigration increases heterogeneity, which should increase tolerance (Stouffer 1955). As migrants increasingly move to the South, its tolerance levels should rise (Carter and Borch 2005). Several studies find that migration has altered the partisan landscape of some areas of the country (Frendreis 1989; Gimpel and Schuknecht 2001; Hood and McKee 2010; Robinson and Noriega 2010). On the other hand, Moore and Vanneman $(2003,132)$ raise the possibility that "people with conservative gender attitudes [may be] more likely to migrate to states where fundamentalism prevails and less likely to migrate away." Gimpel and Schuknecht (2001) find that, because migration is costly, migrants tend to be Republicans. McDonald $(2010,516)$ notes that Bush won 45 of the 50 fastestgrowing congressional districts in 2004 and that "[i]n 2008, despite winning in 240 of 435 districts overall, Obama won majorities in only 13 of the 50 fastest growing districts." His analysis shows that "an individual migrant's destination is more likely than not to provide a closer ideological match than the place from which the migrant left" (McDonald 2010, 530). If evangelicals are disproportionately moving into the South and non-evangelicals are disproportionately moving out, for instance, regional differences could widen.

In sum, we expect opposition to SSM and lesbian and gay rights to be notably stronger in the South than in the rest of the country, but we have no prediction of whether that difference is widening or narrowing. We expect that regional differences in religiosity, religion, conservatism, party identifi- 
cation, age, education, race/ethnicity, and gender partially account for that difference, and we will assess the relative importance of each factor in explaining the South's greater resistance to SSM. We also expect that the greater concentration of religious and political conservatives in the South creates contextual effects that make Southerners more likely to oppose lesbian and gay rights than demographically similar people in the rest of the country. We explore two possible mechanisms. First, a greater concentration of evangelicals and political conservatives may create a climate that increases resistance across the board. Second, one's own evangelism and conservatism may have greater effects in the South, due to the greater number of peers. Finally, we examine the impact of migration on regional divergence on lesbian and gay rights but make no strong predictions.

\section{Data and Methods}

We began with iPOLL searches of the holdings of the Roper Center for Public Opinion Research to find national surveys that asked whether homosexual sex should be legal, whether schools should hire (or have the right to fire) homosexual teachers, or whether SSM should be valid. We obtained individual-level data for 32 surveys on legalization of homosexual sex (40,000 respondents between 1977 and 2005), 33 surveys on homosexual teachers (44,000 respondents between 1977 and 2009), and 100 surveys on SSM (126,000 respondents between 1992 and 2011). We also use the 19742010 General Social Surveys (GSS), which have 32,000 responses on whether consensual homosexual relations are wrong.

In most of our analyses, we define the South as the Confederacy (Alabama, Arkansas, Florida, Georgia, Louisiana, Mississippi, North Carolina, South Carolina, Tennessee, Texas, and Virginia), plus Kentucky, Oklahoma, and West Virginia. The GSS and two other surveys only identify respondents' Census region, forcing us to include Maryland, Delaware, and the District of Columbia in the South. This will tend to understate differences between the South and the rest of the United States (RUS) because support for lesbian and gay rights is higher in the District of Columbia than in any state; opinion in Maryland places it in the mid-Atlantic rather than the South; and Delaware resembles Florida, the most liberal of the Southern states on gay issues. Support for SSM is about 10 percentage points higher in these states than in the South, and their inclusion inflates the size of the South by about 10 percent.

We begin by trying to determine how much more negative attitudes are in the South than in RUS. We perform difference-of-proportions tests for each question in each survey. We then conduct essentially bivariate logit analyses, combining all surveys on legality, teachers, SSM, and the wrong- 
ness of homosexual relations into four analyses. A dichotomous variable for the South is the key independent variable, but we add a dummy variable for each survey included in the analysis. The GSS asks identical questions across multiple surveys, but the other analyses combine a variety of questions asked by a variety of polling firms. In each case, we code the pro-gay rights response (supporting SSM and the employment of lesbian and gay teachers, favoring legalization of homosexual sex, and stating that homosexual sex is "not wrong at all") as 1 and all other responses (including "Don't know" and refusals to answer) as 0 . Individual survey dummy variables should capture question wording and house effects, as well as controlling for changes in attitudes over time. We capture time trends in the GSS analysis by adding dummy variables for each survey year. The coefficient on South thus represents average differences in the log-odds of giving the progay rights response between Southerners and other Americans on the same survey. (All analyses use the weights provided in the surveys.)

To test whether those differences have grown or shrunk over time, we create a time variable representing the month and year in which the survey was conducted and interact it with the South dummy variable. We cannot add the time variable itself to the model, since it is perfectly collinear with the survey or year dummy variables, but the coefficient on the interaction term tests whether support is growing faster or slower in the South. These dummy variables do not impose any pattern on time trends in support, but the linear interaction term assumes that the South-RUS gap is widening or narrowing at a constant pace. As convergence or divergence may have quickened or slowed over time, we also test the interaction term just on surveys conducted since 2000 .

Next, we examine the sources of regional differences in support for lesbian and gay rights. We run logit models for each dependent variable controlling for religiosity, religion, conservatism, party identification, age, education, race/ethnicity, and gender. As shown in Table 1, we measure most variables as sets of dummy variables - four for frequency of attendance at religious services, with "never" as the reference group; five for religious affiliation, with mainline (non-evangelical) Protestants as the reference group; four for political ideology, with moderates as the reference group; four for party identification, with independents who don't lean toward either party as the reference group; four or five for educational attainment, with high school graduates as the reference group; and four for race/ethnicity, with non-Hispanic whites as the reference group. The gender dummy variable is coded 1 for the men. Because we are combining survey data over a long period, we substitute year of birth for age; following Lewis and Edwards (2011), we use a spline regression, based on their finding that support rises linearly with year of birth, but in three separate periods: up to 1950 , from 1950 to 1963, and from 1963 onward. 


\section{Table 1. Logit Models for Support for Gay Rights (Multiple Imputation)}

\begin{tabular}{|c|c|c|c|c|}
\hline & Legality & Teachers & SSM & Not Wrong \\
\hline South & $\begin{array}{c}-0.32 * * \\
(10.88)\end{array}$ & $\begin{array}{c}-0.44 * * \\
(15.91)\end{array}$ & $\begin{array}{c}-0.30 * * \\
(14.94)\end{array}$ & $\begin{array}{l}-0.42^{* *} \\
(11.18)\end{array}$ \\
\hline Never attends church & - & - & - & - \\
\hline Attends annually & - & - & $\begin{array}{l}-0.27 * * \\
(8.55)\end{array}$ & $\begin{array}{l}-0.27 * * \\
(6.26)\end{array}$ \\
\hline Attends monthly & - & - & $\begin{array}{c}-0.56^{* *} \\
(11.76)\end{array}$ & $\begin{array}{c}-0.55^{* *} \\
(10.25)\end{array}$ \\
\hline Attends church almost weekly & - & - & $\begin{array}{l}-0.76^{* *} \\
(11.67)\end{array}$ & $\begin{array}{l}-1.05^{* *} \\
(11.36)\end{array}$ \\
\hline Attends church weekly & $\begin{array}{c}-0.78^{* *} \\
(22.93)\end{array}$ & $\begin{array}{l}-0.45^{* *} \\
(9.34)\end{array}$ & $\begin{array}{l}-1.06^{* *} \\
(22.83)\end{array}$ & $\begin{array}{c}-1.33^{*} \\
(24.01)\end{array}$ \\
\hline Democrat & $\begin{array}{c}0.02 \\
(0.34)\end{array}$ & $\begin{array}{l}-0.02 \\
(0.70)\end{array}$ & $\begin{array}{c}0.33^{* *} \\
(10.39)\end{array}$ & $\begin{array}{l}0.23 * * \\
(4.49)\end{array}$ \\
\hline Leans Democratic & $\begin{array}{l}0.22 * * \\
(3.49)\end{array}$ & $\begin{array}{c}0.15 \\
(1.85)\end{array}$ & $\begin{array}{l}0.36^{* *} \\
(9.89)\end{array}$ & $\begin{array}{l}0.35^{* *} \\
(5.78)\end{array}$ \\
\hline Independent & - & - & - & - \\
\hline Leans Republican & $\begin{array}{l}-0.04 \\
(0.67)\end{array}$ & $\begin{array}{l}-0.09 \\
(1.25)\end{array}$ & $\begin{array}{l}-0.24 * * \\
(5.80)\end{array}$ & $\begin{array}{c}0.05 \\
(0.77)\end{array}$ \\
\hline Republican & $\begin{array}{l}-0.16 * * \\
(3.52)\end{array}$ & $\begin{array}{l}-0.23^{* *} \\
(6.14)\end{array}$ & $\begin{array}{c}-0.52^{* *} \\
(15.15)\end{array}$ & $\begin{array}{l}-0.14^{*} \\
(2.39)\end{array}$ \\
\hline Very liberal & $\begin{array}{c}0.45^{* *} \\
(4.59)\end{array}$ & $\begin{array}{c}0.59 * * \\
(7.92)\end{array}$ & $\begin{array}{c}0.83^{* *} \\
(17.17)\end{array}$ & $\begin{array}{c}1.11^{* *} \\
(12.47)\end{array}$ \\
\hline Liberal & $\begin{array}{c}0.37 * * \\
(7.53)\end{array}$ & $\begin{array}{c}0.40 * * \\
(7.76)\end{array}$ & $\begin{array}{c}0.62 * * \\
(25.21)\end{array}$ & $\begin{array}{c}0.53^{* *} \\
(13.30)\end{array}$ \\
\hline Moderate & - & - & - & - \\
\hline Conservative & $\begin{array}{c}-0.46^{* *} \\
(12.45)\end{array}$ & $\begin{array}{l}-0.41^{* *} \\
(7.94)\end{array}$ & $\begin{array}{c}-0.61 * * \\
(25.64)\end{array}$ & $\begin{array}{l}-0.26 * * \\
(5.66)\end{array}$ \\
\hline Very conservative & $\begin{array}{c}-0.79 * * \\
(10.61)\end{array}$ & $\begin{array}{c}-0.74 * * \\
(10.44)\end{array}$ & $\begin{array}{c}-1.00 * * \\
(18.79)\end{array}$ & $\begin{array}{l}-0.53 * * \\
(3.94)\end{array}$ \\
\hline Less than high school graduate & $\begin{array}{l}-0.30 * * \\
(6.34)\end{array}$ & $\begin{array}{l}-0.30 * * \\
(7.10)\end{array}$ & $\begin{array}{l}-0.19 * * \\
(4.74)\end{array}$ & $\begin{array}{l}-0.21 * * \\
(3.88)\end{array}$ \\
\hline High school graduate & - & - & - & - \\
\hline Technical training beyond h.s. & $\begin{array}{l}0.31 * * \\
(3.80)\end{array}$ & $\begin{array}{c}0.16^{*} \\
(2.32)\end{array}$ & $\begin{array}{c}0.15^{*} \\
(2.50)\end{array}$ & - \\
\hline Some college & $\begin{array}{c}0.49 * * \\
(14.04)\end{array}$ & $\begin{array}{c}0.47 * * \\
(14.22)\end{array}$ & $\begin{array}{l}0.24 * * \\
(9.88)\end{array}$ & $\begin{array}{l}0.29 * * \\
(4.65)\end{array}$ \\
\hline
\end{tabular}


Table 1. (continued)

\begin{tabular}{|c|c|c|c|c|}
\hline & Legality & Teachers & SSM & Not Wrong \\
\hline College graduate & $\begin{array}{c}0.89^{* *} \\
(24.41)\end{array}$ & $\begin{array}{c}0.86^{* *} \\
(23.55)\end{array}$ & $\begin{array}{c}0.51^{* *} \\
(20.66)\end{array}$ & $\begin{array}{c}0.73 * * \\
(17.56)\end{array}$ \\
\hline Graduate degree & $\begin{array}{c}1.17^{* * *} \\
(22.83)\end{array}$ & $\begin{array}{c}0.95^{* *} \\
(14.10)\end{array}$ & $\begin{array}{c}0.73^{* *} \\
(26.88)\end{array}$ & $\begin{array}{c}1.06^{* *} \\
(16.59)\end{array}$ \\
\hline Year of birth (pre-1950) & $\begin{array}{c}0.026^{* *} \\
(16.59)\end{array}$ & $\begin{array}{c}0.023^{* *} \\
(15.15)\end{array}$ & $\begin{array}{l}0.028^{* *} \\
(17.05)\end{array}$ & $\begin{array}{l}0.024^{* *} \\
(12.34)\end{array}$ \\
\hline Year of birth (1950-63) & $\begin{array}{r}0.005 \\
(1.27)\end{array}$ & $\begin{array}{l}0.010^{* * *} \\
(2.85)\end{array}$ & $\begin{array}{l}0.016^{* *} \\
(5.69)\end{array}$ & $\begin{array}{c}0.008 \\
(1.78)\end{array}$ \\
\hline Year of birth (post-1963) & $\begin{array}{l}0.029 * * \\
(6.65)\end{array}$ & $\begin{array}{l}0.020 * * \\
(5.27)\end{array}$ & $\begin{array}{l}0.032 * * \\
(18.40)\end{array}$ & $\begin{array}{l}0.026 * * \\
(6.21)\end{array}$ \\
\hline Evangelical Protestant & $\begin{array}{l}-0.58 * * \\
(8.29)\end{array}$ & $\begin{array}{l}-0.44 * * \\
(9.62)\end{array}$ & $\begin{array}{c}-0.77 * * \\
(24.46)\end{array}$ & $\begin{array}{c}-0.49 * * \\
(10.05)\end{array}$ \\
\hline Mainline Protestant & - & - & - & - \\
\hline Catholic & $\begin{array}{c}0.14^{*} \\
(2.83)\end{array}$ & $\begin{array}{c}0.28 * * \\
(7.28)\end{array}$ & $\begin{array}{l}0.11 * * \\
(3.76)\end{array}$ & $\begin{array}{c}0.19 * * \\
(4.42)\end{array}$ \\
\hline Jewish & $\begin{array}{c}0.73 * * \\
(7.20)\end{array}$ & $\begin{array}{c}0.73^{* *} \\
(7.32)\end{array}$ & $\begin{array}{c}0.76^{* *} \\
(11.89)\end{array}$ & $\begin{array}{l}1.00^{* *} \\
(9.97)\end{array}$ \\
\hline Other religion & $\begin{array}{l}-0.18^{*} \\
(2.42)\end{array}$ & $\begin{array}{l}-0.17 * \\
(2.46)\end{array}$ & $\begin{array}{l}-0.01 \\
(0.34)\end{array}$ & $\begin{array}{l}0.36^{* *} \\
(3.82)\end{array}$ \\
\hline No religion & $\begin{array}{c}0.36^{* *} \\
(5.29)\end{array}$ & $\begin{array}{l}0.34 * * \\
(6.34)\end{array}$ & $\begin{array}{c}0.40^{* *} \\
(12.13)\end{array}$ & $\begin{array}{c}0.50^{* *} \\
(9.03)\end{array}$ \\
\hline Male & $\begin{array}{l}-0.27 * * \\
(9.55)\end{array}$ & $\begin{array}{c}-0.52 * * \\
(18.93)\end{array}$ & $\begin{array}{l}-0.51 * * \\
(26.84)\end{array}$ & $\begin{array}{c}-0.43 * * \\
(12.80)\end{array}$ \\
\hline White non-Hispanic & - & - & - & - \\
\hline Black & $\begin{array}{l}-0.24 * * \\
(4.25)\end{array}$ & $\begin{array}{l}0.12 * * \\
(2.58)\end{array}$ & $\begin{array}{c}-0.42^{* *} \\
(11.68)\end{array}$ & $\begin{array}{l}-0.37 * * \\
(6.26)\end{array}$ \\
\hline Latino & $\begin{array}{l}-0.24 * * \\
(3.90)\end{array}$ & $\begin{array}{l}-0.21 * * \\
(3.32)\end{array}$ & $\begin{array}{l}-0.20 * * \\
(5.10)\end{array}$ & $\begin{array}{l}-0.29 * * \\
(3.00)\end{array}$ \\
\hline Asian & $\begin{array}{l}-0.61 * * \\
(3.99)\end{array}$ & $\begin{array}{l}-0.24 \\
(1.16)\end{array}$ & $\begin{array}{l}-0.58 * * \\
(8.07)\end{array}$ & $\begin{array}{l}-0.72 * * \\
(4.18)\end{array}$ \\
\hline Other minority & $\begin{array}{l}-0.35^{* *} \\
(4.02)\end{array}$ & $\begin{array}{l}-0.05 \\
(0.64)\end{array}$ & $\begin{array}{l}-0.24 * * \\
(4.86)\end{array}$ & $\begin{array}{l}-0.51 * * \\
(4.71)\end{array}$ \\
\hline Sample size & 40,266 & 44,049 & 123,066 & 29,160 \\
\hline
\end{tabular}


We deal with missing values in two ways. In Table 1, we perform multiple imputation using the "ice" and "mim" programs in Stata (Royston 2005). Many surveys failed to ask questions about independent variables we include in the model. Surveys in the 1970s and 1980s frequently did not ask about church attendance and political ideology. Many surveys did not ask about religious affiliation, and many that did, did not ask whether respondents considered themselves born-again or evangelical Christians. Multiple imputation makes better use of these data than dropping everyone with a missing value, especially for the legality and teacher analyses, where 90 percent of the observations had at least one missing value.

Imputation requires assumptions about the consistency of inter-relationships among variables that may not hold up across multiple surveys over such long periods, however. Therefore, analyses in the other tables use listwise deletion of missing values. We focus on attitudes toward SSM and homosexual relations, because we have so much data on SSM (even after losing 61 surveys that did not measure all our variables, we still have 52,700 respondents to 39 surveys that did) and because the General Social Survey has been consistent enough in its questions that we lose relatively few observations on homosexual relations.

The logit coefficient on South represents the difference in log-odds of supporting gay rights between Southerners and non-Southerners who are the same on the other variables in the model. Because probabilities are nonlinear transformations of log-odds, logit coefficients translate into different probability changes from a one-unit increase in a variable at different prior probabilities (before the one-unit increase). For the multiple imputation analyses, we use a simple method (partly because the "ice" and "mim" programs do not support more sophisticated approaches): We take the percentage of nonSoutherners who gave the gay-positive response on that variable across all surveys on that topic as the prior probability.

For the remaining analyses, we translate logit coefficients into probability differences using the average partial effect method (Wooldridge 2009, 582). Essentially, this method calculates the expected effect of being Southern for each person in the data set, based on his or her other characteristics, and then calculates the mean of those effects. We have Stata predict each respondent's probability of supporting SSM twice, once as a Southerner (coding South=1) and once as a non-Southerner (coding South=0). In the full marriage model, based on one's other characteristics, being Southern decreased one's probability of favoring SSM by anywhere from 0.1 to 6.1 percentage points; the mean effect was 3.9 percentage points. We use the same approach to estimate the effects of the other independent variables, for instance calculating five probabilities for each person as if she were very liberal, liberal, moderate, conservative, or very conservative. 
To test for contextual effects, we take two approaches. First, we include the percentage of each state's respondents who are evangelical Protestant and the mean level of conservatism in the state in the SSM model. (The GSS does not identify the state in which the respondent lives.) We calculate these means and percentages based on the full sample of 126,000 SSM respondents (91,000 indicate whether they are evangelicals and 112,000 report their ideology). We cluster the standard errors by state. We examine how both the South and other coefficients change when these variables are included. Second, we test whether religiosity, religion, conservatism, party identification, age, education, race/ethnicity, and gender have different effects on attitudes for Southerners and other Americans. We run separate logit models for each region. We also create interaction terms between South and all the other independent variables (except the survey dummy variables) to test whether apparent differences in coefficients are statistically significant.

If the concentration of religious and political conservatives in the South increases moral traditionalism across the board, the first analysis should show strong effects of the state-level measures of evangelism and conservatism, but the other coefficients should change little. If that concentration strengthens resistance to lesbian and gay rights particularly among evangelicals or conservatives, the effects of those variables should be stronger in the South than in RUS.

Next, we gauge the relative importance of each variable in explaining regional differences in support for SSM. That importance depends both on the strength of each variable's impact on support for SSM and on the regional differences on that variable. We calculate regional differences on these variables based on the 116,550 respondents to the 91 surveys on SSM conducted since 2000 . We run several logit models for each dependent variable (support for SSM and belief that homosexual relations are "not wrong at all"). Table 2 shows both the base model, with the survey or year dummy variables as the only controls, and the full model, which adds all the independent variables. We translate each South coefficient into a probability difference; the former is our best estimate of the "gross" regional difference, while the latter yields the regional difference that cannot be explained by differences in individual religious, political, and demographic characteristics. We then drop one set of independent variables at a time from the full model. If the South coefficient grows when that set of dummy variables is dropped from the full model, regional differences on that independent variable are contributing to the regional differences on support for SSM and acceptance of homosexuality. The more the coefficient grows, the more important that set of variables is in explaining the regional attitudinal difference. $^{1}$ 
Table 2. Logit Models (Listwise Deletion)

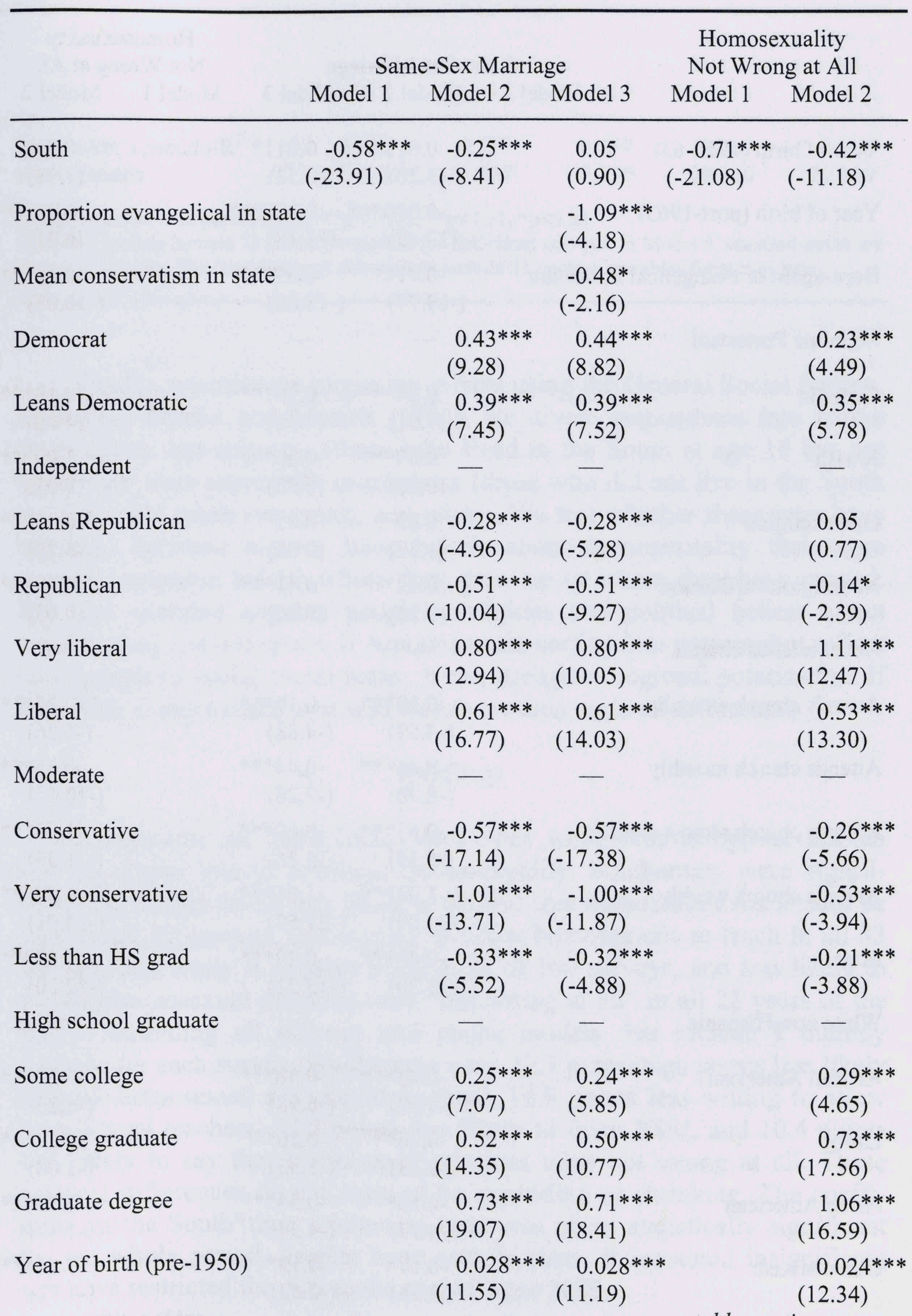


Table 2. (continued)

\begin{tabular}{|c|c|c|c|c|}
\hline & \multicolumn{2}{|c|}{ Same-Sex Marriage } & \multicolumn{2}{|c|}{$\begin{array}{l}\text { Homosexuality } \\
\text { Not Wrong at All }\end{array}$} \\
\hline Model 1 & Model 2 & Model 3 & Model 1 & Model 2 \\
\hline Year of birth (1950-63) & $\begin{array}{l}0.011^{* *} \\
(3.20)\end{array}$ & $\begin{array}{l}0.011^{*} \\
(2.52)\end{array}$ & & $\begin{array}{r}0.008 \\
(1.78)\end{array}$ \\
\hline Year of birth (post-1963) & $\begin{array}{l}0.030^{* * *} \\
(13.47)\end{array}$ & $\begin{array}{l}* .030 * * * \\
(13.18)\end{array}$ & & $\begin{array}{l}0.026^{* * * *} \\
(6.21)\end{array}$ \\
\hline Born-again or evangelical Protestant & $\begin{array}{l}-0.71 * * * \\
(-19.77)\end{array}$ & $\begin{array}{l}-0.69 * * * \\
(-18.88)\end{array}$ & & $\begin{array}{l}-0.49 * * * \\
(-10.05)\end{array}$ \\
\hline Mainline Protestant & - & - & & - \\
\hline Catholic & $\begin{array}{l}0.24 * * * \\
(7.01)\end{array}$ & $\begin{array}{l}0.20 * * * \\
(4.36)\end{array}$ & & $\begin{array}{l}0.19 * * * \\
(4.42)\end{array}$ \\
\hline Jewish & $\begin{array}{l}0.87 * * * \\
(10.67)\end{array}$ & $\begin{array}{l}0.80 * * * \\
(6.53)\end{array}$ & & $\begin{array}{l}1.00 * * * \\
(9.97)\end{array}$ \\
\hline Other religion & $\begin{array}{c}0.09 \\
(1.39)\end{array}$ & $\begin{array}{c}0.07 \\
(0.85)\end{array}$ & & $\begin{array}{l}0.36 * * * \\
(3.82)\end{array}$ \\
\hline No religious affiliation & $\begin{array}{l}0.42 * * * \\
(9.14)\end{array}$ & $\begin{array}{l}0.41 * * * \\
(9.30)\end{array}$ & & $\begin{array}{l}0.50 * * * \\
(9.03)\end{array}$ \\
\hline Never attends church & - & - & & - \\
\hline Attends church annually & $\begin{array}{l}-0.20 * * * \\
(-4.59)\end{array}$ & $\begin{array}{l}-0.19 * * * \\
(-4.88)\end{array}$ & & $\begin{array}{l}-0.27 * * * \\
(-6.26)\end{array}$ \\
\hline Attends church monthly & $\begin{array}{l}-0.46^{* * *} \\
(-8.70)\end{array}$ & $\begin{array}{l}-0.44 * * * \\
(-7.28)\end{array}$ & & $\begin{array}{l}-0.55 * * * \\
(-10.25)\end{array}$ \\
\hline Attends church almost weekly & $\begin{array}{l}-0.63 * * * \\
(-5.15)\end{array}$ & $\begin{array}{l}-0.60 * * * \\
(-5.26)\end{array}$ & & $\begin{array}{l}-1.05^{* * *} \\
(-11.36)\end{array}$ \\
\hline Attends church weekly & $\begin{array}{l}-1.04 * * * \\
(-21.09)\end{array}$ & $\begin{array}{l}-1.01 * * * \\
(-21.57)\end{array}$ & & $\begin{array}{l}-1.34 * * * \\
(-24.01)\end{array}$ \\
\hline Male & $\begin{array}{l}-0.49 * * * \\
(-18.20)\end{array}$ & $\begin{array}{l}-0.49 * * * \\
(-15.22)\end{array}$ & & $\begin{array}{l}-0.43 * * * \\
(-12.80)\end{array}$ \\
\hline White non-Hispanic & - & - & & - \\
\hline African American & $\begin{array}{l}-0.48 * * * \\
(-9.52)\end{array}$ & $\begin{array}{l}-0.50 * * * \\
(-6.98)\end{array}$ & & $\begin{array}{l}-0.37 * * * \\
(-6.26)\end{array}$ \\
\hline Latino & $\begin{array}{l}-0.16^{* *} \\
(-3.13)\end{array}$ & $\begin{array}{l}-0.20^{* * *} \\
(-3.33)\end{array}$ & & $\begin{array}{l}-0.29 * * * \\
(-3.00)\end{array}$ \\
\hline Asian American & $\begin{array}{l}-0.50 * * * \\
(-4.77)\end{array}$ & $\begin{array}{l}-0.54 * * * \\
(-4.34)\end{array}$ & & $\begin{array}{l}-0.72 * * * \\
(-4.18)\end{array}$ \\
\hline Other/Mixed & $\begin{array}{c}-0.17^{*} \\
(-2.35)\end{array}$ & $\begin{array}{c}-0.19 * \\
(-2.53)\end{array}$ & & $\begin{array}{l}-0.51 * * * \\
(-4.71)\end{array}$ \\
\hline
\end{tabular}




\begin{tabular}{|c|c|c|c|c|c|}
\hline & \multicolumn{3}{|c|}{ Same-Sex Marriage } & \multicolumn{2}{|c|}{$\begin{array}{l}\text { Homosexuality } \\
\text { Not Wrong at All }\end{array}$} \\
\hline & Model 1 & Model 2 & Model 3 & Model 1 & Model 2 \\
\hline McFadden's pseudo- $\mathrm{R}^{2}$ & 0.025 & 0.237 & 0.239 & 0.060 & 0.216 \\
\hline Observations & 52,737 & 52,737 & 52,737 & 29,160 & 29,160 \\
\hline
\end{tabular}

Finally, we examine migration effects using the General Social Survey. Following Ellison and Musick (1993), we divide respondents into native Southerners, out-migrants (those who lived in the South at age 16 but not when they were surveyed), in-migrants (those who did not live in the South at 16 but did when surveyed), and others. We test whether those who have migrated between regions have beliefs about homosexuality that more strongly resemble beliefs where they grew up or where they have moved. We also examine whether people's religious and political beliefs affect whether they cross-migrate. If Americans are sorting into regions that reflect their beliefs on social issues better, it can strengthen regional polarization. If migration is more random, it will tend to weaken regional differences.

\section{Findings}

Southerners are more likely than other Americans to oppose lesbian and gay rights and to condemn homosexuality. Southerners were significantly (at the .05 level) less likely to believe that homosexual sex should be legal in all 32 surveys, less willing to allow homosexuals to teach in all 33 surveys, less likely to support SSM in 95 of 100 surveys, and less likely to say that homosexual relations were "not wrong at all" in all 22 years of the GSS. Combining all surveys into single models that include a dummy variable for each survey, Southerners were 12.7 percentage points less likely to think homosexual sex should be legal, 14.9 points less willing to allow homosexual teachers, 12.5 points less likely to favor SSM, and 10.4 points less likely to say that homosexual relations were not wrong at all. These regional differences do not seem to be expanding or shrinking. The coefficient on the South*time interaction term was never statistically significant for the whole period, despite huge sample sizes. It remained insignificant when we restricted the data to the period since 2000 . 
Differences in religiosity, religion, conservatism, party identification, education, age, race/ethnicity, and gender account for up to half of the regional differences in support for lesbian and gay rights and acceptance of homosexuality (Table 1). Adding these control variables shrinks the South logit coefficient in the legality model from -.51 (in a model with dummy variables for the surveys as the only control variables) to -.32 in a model using the full set of control variables (and using multiple imputation). This translates into cutting the regional difference from 12.7 to 8.0 percentage points. The South logit coefficient also shrinks from -.60 to -.44 in the teacher model (decreasing the percentage difference from 14.9 to 11.0 ), from -.58 to -.30 in the SSM model (with the percentage gap narrowing from 12.5 to 6.9 points), and from -.72 to -.42 in the acceptability of homosexuality model (lowering the difference from 10.4 to 6.8 percentage points).

In the SSM model with listwise deletion rather than multiple imputation (Table 2), which drops the sample size by more than half, the South coefficient shrinks a bit more when the compositional variables are added (from -.58 to -.25). Adding the contextual variables (Model 3) shows that comparable individuals were more likely to oppose SSM when a higher percentage of respondents in their state were evangelical Protestants and when the average person in their state was more conservative. The South coefficient flipped to a statistically insignificant, positive .05 , primarily due to inclusion of the state evangelism measure. The South coefficient grows trivially (to .06) when the conservatism measure is dropped; including the conservatism measure without the evangelism measure also shrinks the South coefficient to statistical insignificance, but to -.05 rather than +.05 . ${ }^{2}$

Consistent with the findings of Moore (Moore and Ovadia 2006; Moore and Vanneman 2003), the contextual effects of high percentages of evangelical Protestants in the state explain the greater Southern opposition to SSM that cannot be accounted for by individual differences on these variables. None of the other coefficients changes meaningfully, and a variety of interaction terms between percent evangelical and other independent variables were not statistically significant, suggesting that the effect of state-level evangelism has a dampening effect on support for SSM across the board rather than on certain sub-groups. Likewise, separate logit models for the South and RUS were strikingly similar for both dependent variables (not shown). In combined models that included full sets of interaction terms between South and all the other independent variables (except survey or year), the full set of interaction terms was barely jointly significant at the .01 level in the marriage model (despite 52,700 observations) and barely jointly significant at the .05 level in the GSS (despite 29,200 observations). The interaction terms that were individually significant (or sets of dummy interaction terms that were jointly significant) were not consistent across the two analy- 
ses. In sum, contextual variables appear to have similar effects across subgroups.

That made us more comfortable using the models from Table 2, assuming the same effects of the independent variables in the South and RUS, for gauging the importance of those variables in explaining regional differences in attitudes. Table 3 shows the mean values of all the variables for the two regions. Table 4 shows the South coefficient from the base model (with the survey or year dummy variables as the only controls) and the full model (including all the independent variables). The remaining lines show how the South coefficient changes when we drop one set of dummy variables from the full model. The difference between each restricted model and the full model represents how adding that set of variables to the model affects the South coefficient.

In the marriage model, for instance, the South coefficient drops from -.580 in the base model to -.245 in the full model. Using the average partial effect approach, Southerners were, on average, 12.6 percentage points less likely than other Americans to favor SSM but only 3.9 percentage points less likely than other Americans of the same religion, politics, education, age, race/ethnicity, and gender to do so. Thus, differences on those characteristics explained 8.7 percentage points of the original 12.6-point difference (more than in the SSM model using imputed data).

\section{Table 3. Mean Characteristics by Region}

\begin{tabular}{lrrr}
\hline & South & $\begin{array}{c}\text { Rest of } \\
\text { United States }\end{array}$ & United States \\
\hline Religious attendance & & & \\
Weekly & 41.2 & 30.5 & 34.1 \\
Almost weekly & 6.6 & 6.0 & 6.2 \\
Once or twice a month & 15.4 & 14.0 & 14.4 \\
A few times a year & 26.6 & 33.2 & 31.0 \\
Never & 10.3 & 16.3 & 14.3 \\
Religious affiliation & & & \\
Evangelical Protestant & 37.2 & 19.9 & 25.8 \\
Mainline Protestant & 33.4 & 29.7 & 31.0 \\
Catholic & 15.4 & 27.6 & 1.7 \\
Jewish & 1.1 & 2.1 & 5.0 \\
Other & 3.4 & 5.8 & 13.1 \\
None & 9.5 & 14.9 &
\end{tabular}


Table 3. (continued)

\begin{tabular}{|c|c|c|c|}
\hline & South & $\begin{array}{c}\text { Rest of } \\
\text { United States }\end{array}$ & United States \\
\hline \multicolumn{4}{|l|}{ Political ideology } \\
\hline Very liberal & 3.7 & 4.4 & 4.2 \\
\hline Liberal & 14.6 & 19.6 & 17.9 \\
\hline Moderate & 38.3 & 40.4 & 39.7 \\
\hline Conservative & 35.9 & 30.4 & 32.2 \\
\hline Very conservative & 7.4 & 5.2 & 5.9 \\
\hline \multicolumn{4}{|l|}{ Party identification } \\
\hline Democrat & 34.9 & 35.0 & 35.0 \\
\hline Leans Democratic & 10.7 & 13.4 & 12.5 \\
\hline Independent & 12.9 & 14.8 & 14.2 \\
\hline Leans Republican & 10.4 & 9.8 & 10.0 \\
\hline Republican & 31.2 & 26.9 & 28.4 \\
\hline \multicolumn{4}{|l|}{ Educational attainment } \\
\hline Less than high school & 14.9 & 10.0 & 11.6 \\
\hline High school graduate & 32.9 & 31.8 & 32.2 \\
\hline Technical training & 2.5 & 2.7 & 2.6 \\
\hline Some college & 24.6 & 26.2 & 25.6 \\
\hline College graduate & 15.3 & 17.3 & 16.6 \\
\hline Graduate degree & 9.9 & 12.2 & 11.4 \\
\hline \multicolumn{4}{|l|}{ Decade of birth } \\
\hline Before 1930 & 5.5 & 5.7 & 5.7 \\
\hline $1930 \mathrm{~s}$ & 8.8 & 8.3 & 8.5 \\
\hline $1940 \mathrm{~s}$ & 13.8 & 13.0 & 13.3 \\
\hline $1950 \mathrm{~s}$ & 18.5 & 18.6 & 18.6 \\
\hline $1960 \mathrm{~s}$ & 20.0 & 20.5 & 20.4 \\
\hline $1970 \mathrm{~s}$ & 17.2 & 17.4 & 17.3 \\
\hline 1980 or later & 16.2 & 16.4 & 16.4 \\
\hline \multicolumn{4}{|l|}{ Race/ethnicity } \\
\hline White & 69.5 & 75.6 & 73.6 \\
\hline Black & 16.9 & 8.8 & 11.5 \\
\hline Latino & 9.5 & 10.0 & 9.9 \\
\hline Asian & 1.0 & 2.1 & 1.7 \\
\hline Other & 3.1 & 3.5 & 3.4 \\
\hline Female & 52.9 & 51.5 & 52.0 \\
\hline
\end{tabular}


Table 4. Impact of Individual Differences on Regional Differences

\begin{tabular}{|c|c|c|c|c|c|c|}
\hline & \multicolumn{3}{|c|}{ Same-Sex Marriage } & \multicolumn{3}{|c|}{ Homosexuality is "not wrong at all" } \\
\hline & $\begin{array}{c}\text { South } \\
\text { Coefficient }\end{array}$ & $\begin{array}{c}\text { Percent } \\
\text { Difference }\end{array}$ & $\begin{array}{l}\text { Amount } \\
\text { Explained }\end{array}$ & $\begin{array}{c}\text { South } \\
\text { Coefficient }\end{array}$ & $\begin{array}{c}\text { Percent } \\
\text { Difference }\end{array}$ & $\begin{array}{l}\text { Amount } \\
\text { Explained }\end{array}$ \\
\hline Base model & -0.580 & 12.6 & - & -0.719 & 10.6 & - \\
\hline Full model & -0.245 & 3.9 & 8.7 & -0.420 & 5.2 & 5.4 \\
\hline Religious affiliation & -0.365 & 6.0 & 2.1 & -0.544 & 6.9 & 1.7 \\
\hline Attendance and affiliation & -0.442 & 7.7 & 3.8 & -0.602 & 7.9 & 2.7 \\
\hline Party identification & -0.269 & 4.5 & 0.6 & -0.423 & 5.3 & 0.1 \\
\hline Political ideology & -0.254 & 4.2 & 0.3 & -0.441 & 5.6 & 0.4 \\
\hline Party and ideology & -0.294 & 5.3 & 1.4 & -0.445 & 5.8 & 0.6 \\
\hline Education & -0.267 & 4.3 & 0.4 & -0.422 & 5.4 & 0.2 \\
\hline
\end{tabular}


Religious differences account for the biggest share of that explanation. Southerners are one-third more likely than other Americans to attend religious services weekly ( $41.2 \%$ versus $30.5 \%)$ and one-third less likely to never attend (10.2\% versus $16.3 \%)$. On average, those who never attended were 17.5 percentage points more likely than similar people who attended weekly to favor SSM. If religious attendance is dropped from the model, the South coefficient rises from -.245 to -.279 , and the unexplained regional difference in attitudes rises from 3.9 to 4.6 percentage points. Thus, differences in religious attendance account for 0.7 percentage points of the regional difference.

More importantly, Southerners are far more likely than others to be evangelical Protestants, only about half as likely to be Catholic or Jewish, and about two-thirds as likely to have no religious affiliation. Evangelical Protestants are 12.6 percentage points less likely to support SSM than comparable mainline Protestants, who are 3.5 points less likely to do so than comparable Catholics, who are 4.5 points less likely to do so than comparable non-religious people, who are 8.0 points less likely to do so than comparable Jews. Regional differences in religious affiliation account for 2.1 percentages points of the regional difference in support for SSM. Because probabilities are a nonlinear function of the independent variables, dropping both the attendance and affiliation variables simultaneously widens the unexplained regional difference from 3.9 to 7.7 percentage points. That is, regional religious differences account for nearly one-third of the regional differences in support for SSM (3.8 out of 12.6 points).

Political differences contribute less to regional differences. Ideology is the second strongest predictor of attitudes toward SSM. Very liberal and liberal respondents are 18.2 and 12.7 percentage points, respectively, more likely to favor SSM than comparable moderates. Comparable conservative and very conservative respondents lag 10.2 and 16.9 points, respectively, behind moderates. However, regional ideological differences are smaller than regional religious differences-Southerners are about 5 percentage points less likely to be liberal and 7 percentage points more likely to be conservative. Dropping the ideology measures from the full model only widens the unexplained difference in support for SSM by 0.3 percentage points.

Political party differences appear smaller. Southerners are 4.9 percentage points more likely to be or to lean Republican. Republicans are 7.5 points less likely than independents and 15.8 points less likely than Democrats to support SSM. However, leaving party identification out of the model increases the South coefficient more than leaving out ideology, and implies that partisan differences account for 0.6 percentage points of the regional difference in support for SSM. Dropping party and ideology simultaneously widens the unexplained difference in support for SSM by 1.4 percentage points, indicating that political differences explain about half as much of the regional difference in support for SSM as the religious differences do. 
Support for SSM rises fairly steadily with education. High school graduates are 4.6 percentage points more likely to favor SSM than comparable individuals who have not completed high school. Some college raises that probability by 4.5 points, a bachelor's degree raises it by another 4.6 points, and a graduate degree increases it by a further 3.0 points. As Southerners are 4.9 percentage points more likely not to have completed high school and 4.3 points less likely to have completed college, regional educational differences account for a 0.4 percentage point difference in support for SSM.

The coefficients on the year-of-birth variables demonstrate the strong role of age. Support for SSM rose with each year of birth, but at different rates in different periods. Someone born in 1946, for instance, had a 0.5 percentage point higher probability of favoring SSM than a comparable person born in 1945, but those born in 1956 were only 0.2 point more likely to favor SSM than those born in 1955, and those born in 1976 were 0.6 point more likely to do so than those born in 1975. Southerners, however, are younger than other Americans, on average. Dropping the age variables from the model shrinks the South coefficient; that is, age differences do not account for any of the regional difference in support for marriage equality.

Finally, support for SSM varies by sex and race/ethnicity, but only one difference really contributes to regional differences. Women are 7.6 percentage points more likely than comparable men to favor marriage equality, but the Southern sample is slightly more female than the RUS sample, so gender differences do not contribute to the South's greater opposition to SSM. Holding the other variables constant, non-Hispanic whites are the most likely to favor SSM, but Latinos only lag 2.6 percentage points behind. African Americans are 8.8 percentage points less likely than whites to support SSM, and Asians lag 1.2 points behind blacks. As Southerners are almost twice as likely as other Americans to be black and are 6 percentage points less likely to be white, dropping race from the model increases the regional difference to 4.3 , implying that regional racial differences account for about 0.4 percentage point of the regional difference in support for SSM.

This conclusion requires two caveats. First, these racial/ethnic differences control for the other variables in the model. This does not affect blackwhite differences much, as blacks' greater liberalism and Democratic party identification and younger age almost perfectly offset their greater religiosity, higher probability of being evangelical Protestants, and lower educational level. Although Asians and Latinos are less likely than comparable whites to favor marriage equality, higher percentages of Latinos and Asians actually favor SSM. Averaging over the surveys since 2005, 46 percent of Asians, 42 percent of Latinos, 38 percent of whites, and 29 percent of blacks said that they supported SSM. Second, although blacks have more negative attitudes toward homosexual sex and SSM than whites do, Table 1 shows 
that they are significantly more likely than comparable whites to favor the hiring of gay teachers, in line with previous findings that blacks are more likely than whites to oppose anti-gay employment discrimination (Boykin 1998; Lewis 2003).

Regional migration does not play much role in widening or narrowing the South-RUS gap on lesbian and gay rights. Table 5 shows that Southerners of all categories are less likely than those who have never lived in the South to say that homosexual relations are "not wrong at all" (Model I). Native Southerners (those who lived in the South both at age 16 and at the time of the survey) were 12.2 percentage points less likely than those who did not live in the South at either time to say that homosexual relations were "not wrong at all." Migrants in both directions had reasonably similar views, which were closer to those who had never lived in the South than to native Southerners. Out-migrants (those who lived in the South at age 16 but moved out) and in-migrants (those who moved to the South after they were 16) were 8.7 and 7.2 points more likely than the native born, respectively, to say that.

Differences in religiosity, religion, conservatism, party identification, age, education, race/ethnicity, and gender accounted for half the split between native Southerners and other non-migrants. Native Southerners were 12.2 percentage points less likely than other non-migrants to say "not wrong at all," but only 5.9 points less likely than similar Americans who had never lived in the South to do so. These differences also explain one-third of the attitudinal difference between in-migrants and non-Southerners. Interestingly, although out-migrants support SSM less than other non-Southerners, they may be more likely to favor it than religiously and politically similar nonSoutherners.

Religious migration may contribute to regional polarization. Those who never attend church are much more likely than weekly attenders to move out of the South, with those who attend occasionally in-between. Catholics, the non-religious (even holding non-attendance constant), Jews, and members of other religions are all more likely than Protestants to leave the South. Evangelical Protestants are significantly more likely than mainline Protestants to move to the South, and the non-religious are significantly less likely to. Of course, these religious patterns could result from, rather than lead to, the migration - the South's stronger religious culture may increase church attendance and draw other Protestants into evangelical congregations, and evangelical Protestants may drift away from the church in less-supportive environments. On the whole, however, migration patterns probably contribute little to the regional divergence on lesbian and gay rights, as in- and outmigrants' attitudes are far more similar to each other than to those who do not migrate. 


\section{Table 5. Logit Models for Wrongness of Homosexuality and Migration Into or Out of South (1974-2010 GSS)}

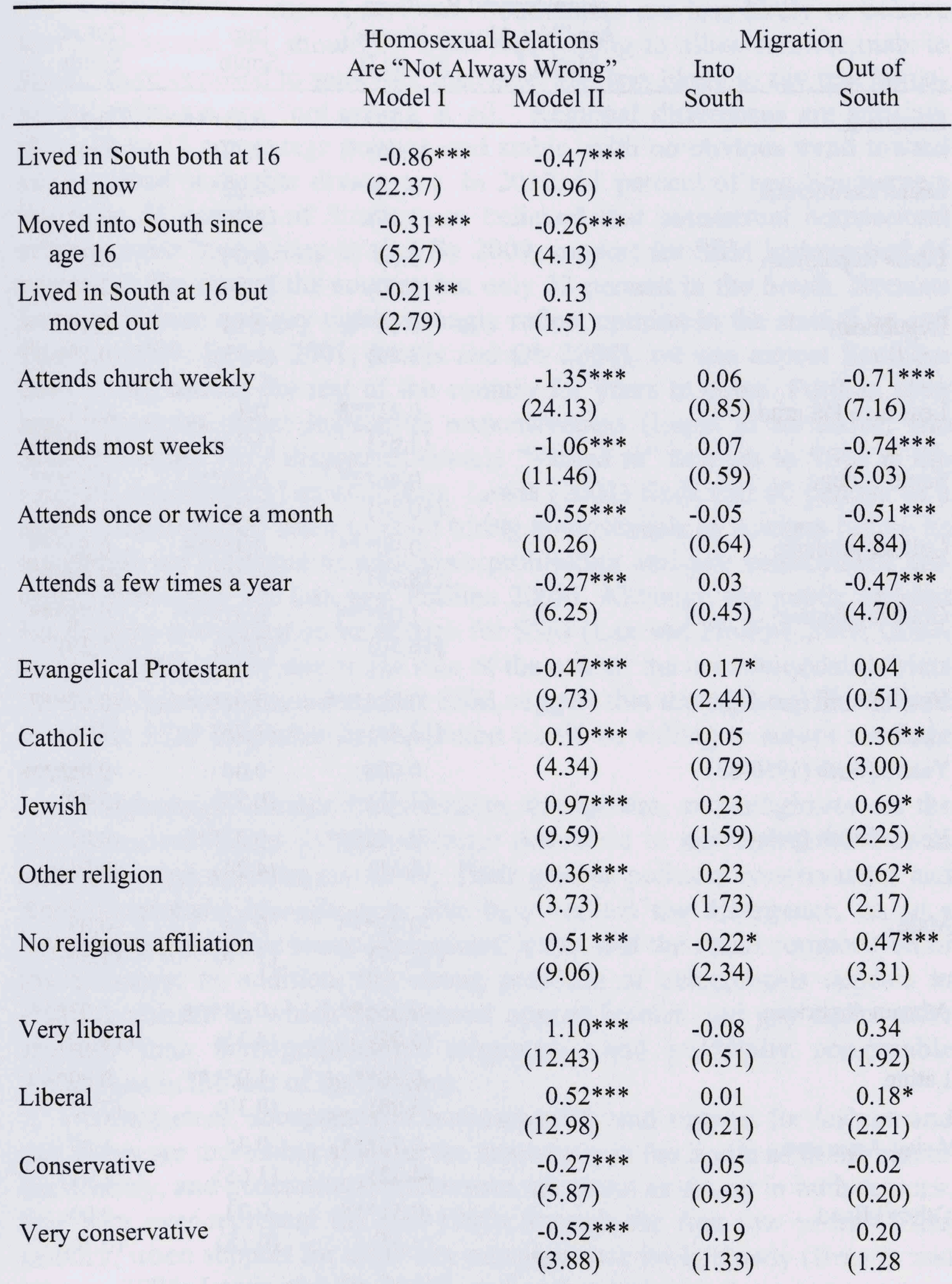


Table 5. (continued)

\begin{tabular}{|c|c|c|c|c|}
\hline & \multirow{2}{*}{\multicolumn{2}{|c|}{$\begin{array}{l}\text { Homosexual Relations } \\
\text { Are "Not Always Wrong" }\end{array}$}} & \multicolumn{2}{|c|}{ Migration } \\
\hline & & & \multirow{2}{*}{$\begin{array}{l}\text { Into } \\
\text { South }\end{array}$} & \multirow{2}{*}{$\begin{array}{l}\text { Out of } \\
\text { South }\end{array}$} \\
\hline & Model I & Model II & & \\
\hline Democrat & & $\begin{array}{l}0.23 * * * \\
(4.48)\end{array}$ & $\begin{array}{l}-0.27 * * * \\
(3.72)\end{array}$ & $\begin{array}{c}0.00 \\
(0.03)\end{array}$ \\
\hline Leans Democratic & & $\begin{array}{l}0.34 * * * \\
(5.70)\end{array}$ & $\begin{array}{l}-0.22^{*} \\
(2.50)\end{array}$ & $\begin{array}{c}0.00 \\
(0.02)\end{array}$ \\
\hline Leans Republican & & $\begin{array}{c}0.04 \\
(0.60)\end{array}$ & $\begin{array}{l}-0.08 \\
(0.84)\end{array}$ & $\begin{array}{l}-0.39 * \\
(2.33)\end{array}$ \\
\hline Republican & & $\begin{array}{l}-0.14^{*} \\
(2.49)\end{array}$ & $\begin{array}{l}-0.13 \\
(1.75)\end{array}$ & $\begin{array}{l}-0.10 \\
(0.79)\end{array}$ \\
\hline Less than HS grad & & $\begin{array}{l}-0.21 * * * \\
(3.87)\end{array}$ & $\begin{array}{l}0.1 \\
(1.33)\end{array}$ & $\begin{array}{l}-0.17 \\
(1.89)\end{array}$ \\
\hline Some college & & $\begin{array}{l}0.46^{* * *} \\
(10.47)\end{array}$ & $\begin{array}{l}0.18 * * \\
(2.75)\end{array}$ & $\begin{array}{l}0.32 * * * \\
(3.56)\end{array}$ \\
\hline College graduate & & $\begin{array}{l}0.90^{* * *} \\
(18.20)\end{array}$ & $\begin{array}{l}0.45^{* * * *} \\
(6.26)\end{array}$ & $\begin{array}{l}0.53 * * * \\
(5.04)\end{array}$ \\
\hline Graduate degree & & $\begin{array}{l}1.05^{* * *} \\
(16.50)\end{array}$ & $\begin{array}{l}0.62 * * * \\
(7.09)\end{array}$ & $\begin{array}{l}0.78 * * * \\
(5.39)\end{array}$ \\
\hline Year of birth (pre-1950) & & $\begin{array}{l}0.024 * * * \\
(12.44)\end{array}$ & $\begin{array}{l}-0.01 * * * \\
(3.98)\end{array}$ & $\begin{array}{l}-0.02 * * * \\
(7.29)\end{array}$ \\
\hline Year of birth (1950-63) & & $\begin{array}{r}0.008 \\
(1.77)\end{array}$ & $\begin{array}{c}0.00 \\
(0.75)\end{array}$ & $\begin{array}{l}-0.05^{* * *} \\
(5.49)\end{array}$ \\
\hline Year of birth (post-1963) & & $\begin{array}{l}0.028 * * * \\
(6.51)\end{array}$ & $\begin{array}{l}-0.03 * * * \\
(4.24)\end{array}$ & $\begin{array}{l}-0.01 \\
(0.61)\end{array}$ \\
\hline Male & & $\begin{array}{l}-0.43^{* * *} \\
(12.77)\end{array}$ & $\begin{array}{c}0.08 \\
(1.70)\end{array}$ & $\begin{array}{l}-0.09 \\
(1.35)\end{array}$ \\
\hline African American & & $\begin{array}{l}-0.36 * * * \\
(6.07)\end{array}$ & $\begin{array}{l}0.38 * * * \\
(4.31)\end{array}$ & $\begin{array}{l}1.03^{* * *} \\
(13.70)\end{array}$ \\
\hline Latino & & $\begin{array}{l}-0.30 * * \\
(3.08)\end{array}$ & $\begin{array}{l}1.05^{* * * *} \\
(9.30)\end{array}$ & $\begin{array}{c}0.69 * \\
(2.42)\end{array}$ \\
\hline Asian American & & $\begin{array}{l}-0.73 * * * \\
(4.32)\end{array}$ & $\begin{array}{c}0.35 \\
(1.65)\end{array}$ & $\begin{array}{c}1.07 \\
(1.41)\end{array}$ \\
\hline Other/Mixed & & $\begin{array}{l}-0.51 * * * \\
(4.65)\end{array}$ & $\begin{array}{l}-0.03 \\
(0.18)\end{array}$ & $\begin{array}{l}-0.09 \\
(0.30)\end{array}$ \\
\hline Observations & 29,160 & 29,160 & 19,848 & 9,312 \\
\hline Robust $z$-statistics in parent & ${ }^{*} \mathrm{p}<0.001$ & $.01, * p<0.05$ & & \\
\hline
\end{tabular}




\section{Conclusion}

Compared to other Americans, Southerners are less likely to believe that homosexual sex should be legal, less willing to allow homosexuals to teach, more opposed to same-sex marriage, and less likely to say that homosexual relations are "not wrong at all." Regional differences are substantial-10 to 15 percentage points - and stable, with no obvious trend toward convergence or further divergence. In 2010, 51 percent of non-Southerners but only 31 percent of Southerners believed that consensual homosexual relation were "not wrong at all." By 2009, support for SSM had reached 44 percent in the rest of the country but only 32 percent in the South. Because laws on lesbian and gay rights strongly reflect opinion in the state (Lax and Phillips 2009; Lewis 2001; Lewis and Oh 2008), we can expect Southern laws to lag behind the rest of the country for years to come. Further, state legal structures affect legislative responsiveness (Lupia et al. 2010), and Southern states have disproportionately "locked in" barriers to SSM in the form of constitutional amendments. Lewis (2001) finds that 60 percent of a state's residents may need to favor hiring homosexuals as teachers before its legislators are prepared to pass laws prohibiting anti-gay employment discrimination (also see Lax and Phillips 2009). Although the public opinion hurdle does not appear to be as high for SSM (Lax and Phillips 2009; Lewis and Oh 2008), partly due to the role of the courts, the constitutional barriers the South has constructed against SSM suggest that the region will continue to outlaw SSM long after its population would be willing to accept marriage equality.

Southerners' greater Protestantism, evangelism, and religiosity are the strongest contributors to their stronger resistance to gay rights, both at an individual and a contextual level. Their greater political conservatism and Republican party identification also help explain the divergence, as, to a lesser extent, do their lower educational levels and the racial composition of the citizenry. In addition, the strong presence of evangelicals appears to create a climate in which Southerners oppose lesbian and gay rights more strongly than demographically, religiously, and politically comparable Americans in the rest of the country.

Nonetheless, acceptance of homosexuality and support for lesbian and gay rights are increasing at about the same pace in the South as in the rest of the country, and generational differences are about as strong in both regions. Our data over-represent the mid-1990s through the first few years of this century, when support for same-sex marriage rose fairly slowly (Brewer and Wilcox 2005; Lewis and Oh 2008), and under-represent the past two years, when the pace has quickened substantially (Silver 2010; Sullivan 2010). Gallup, for instance, finds a 9 percentage point jump in support for SSM 
between 2010 and 2011 (Newport 2011), and the Pew Research Center (2011) reports 10 point increases between 2009 and 2011 among Americans in the same birth cohort. Since August 2010, several surveys have found Americans evenly split on SSM, with some reporting that a majority of Americans now favor it (Americans Split Evenly on Gay Marriage 2010; Fewer Are Angry at Government, But Discontent Remains High 2011; Langer 2011; Sherkat 2011). Currently, Southerners remain split on employment discrimination, while most Americans oppose it, and they still strongly oppose SSM, while other Americans are split. Within a decade, however, Southerners may be where the rest of the country is now.

\section{NOTES}

${ }^{1}$ If we add variable $\mathrm{X} 2$ to a bivariate linear regression model (with $\mathrm{Y}$ as the dependent variable and $\mathrm{X} 1$ as the independent variable, the coefficient on $\mathrm{X} 1$ changes by (the coefficient on variable $\mathrm{X} 1$ in a model where $\mathrm{X} 2$ is the dependent variable) * (the coefficient on variable $\mathrm{X} 2$ in the model with $\mathrm{Y}$ as the dependent variable). Due the nonlinearities in the logit model, combined with the extra complications of using a set of dummy variables rather than a single variable to represent a characteristic, changes in logit coefficients and probability changes are not as simple, but the general principle holds.

${ }^{2}$ When we ran xtmixed in Stata on all 100 surveys, inter-state variation accounted for 3.4 percent of the total variation in support for SSM and state-level evangelism and political conservatism accounted for 96 percent of the inter-state variation. The South coefficient was not statistically significant once state-level evangelism was in the model.

\section{REFERENCES}

Abrahamson, Mark, and Valerie J. Carter. 1986. Tolerance, Urbanism, and Region. American Sociological Review 51(2):287-294.

Aistrup, Joseph A. 2010. Southern Political Exceptionalism? Presidential Voting in the South and Non-South. Social Science Quarterly 91(4):906-927.

Americans Split Evenly on Gay Marriage. 2010. CNN Politics, August 11.

Books, John, and Charles Prysby. 1988. Studying Contextual Effects on Political Behavior: A Research Inventory and Agenda. American Politics Research 16(2):211238.

Boykin, Keith. 1998. One More River to Cross: Black and Gay in America. New York: Anchor Books Doubleday.

Brewer, Paul R. 2003. The Shifting Foundations of Public Opinion about Gay Rights. Journal of Politics 65(4):1208-1220.

Brewer, Paul R., and Clyde Wilcox. 2005. The Polls-Trends: Same-Sex Marriage and Civil Unions. Public Opinion Quarterly 69(4):599-616.

Burdette, Amy M., Christopher G. Ellison, and Terrence D. Hill. 2005. Conservative Protestantism and Tolerance toward Homosexuals: An Examination of Potential Mechanisms. Sociological Inquiry 75(2):177-196. 
Carter, J. Scott, and Casey A. Borch. 2005. Assessing the Effects of Urbanism and Regionalism on Gender-Role Attitudes, 1974-1998. Sociological Inquiry 75(4): 548-563.

Chauncey, George. 1995. Gay New York: Gender, Urban Culture, and the Making of the Gay Male World, 1890-1940. New York: Basic Books.

Cook, Elizabeth Adell, Ted G. Jelen, and Clyde Wilcox. 1993. State Political Cultures and Public Opinion about Abortion. Political Research Quarterly 46(4):771-781.

DiMaggio, Paul, John Evans, and Bethany Bryson. 1996. Have Americans' Social Attitudes Become More Polarized? American Journal of Sociology 102(3):690.

Ellison, Christopher G., and Marc A. Musick. 1993. Southern Intolerance: A Fundamentalist Effect? Social Forces 72(2):379-398.

Evans, John H. 2003. Have Americans' Attitudes Become More Polarized?-An Update. Social Science Quarterly 84(1):71-90.

Fewer Are Angry at Government, But Discontent Remains High. 2011. In The Pew Research Center for the People \& the Press Survey Reports. Washington, DC.

Frendreis, John P. 1989. Migration as a Source of Changing Party Strength. Social Science Quarterly 70(1):211-220.

Gimpel, James G., and Jason E. Schuknecht. 2001. Interstate Migration and Electoral Politics. Journal of Politics 63(1):207-231.

Grapes, Katharine. 2006. Ignorant Discrimination: How Education Levels Affect Attitudes Toward Homosexuality and Gay Rights. Sociological Viewpoints 22:51-59.

Haider-Markel, Donald P., and Mark R. Joslyn. 2008. Beliefs about the Origins of Homosexuality and Support for Gay Rights. Public Opinion Quarterly 72(2):291-310.

Herek, Gregory M. 1988. Heterosexuals' Attitudes toward Lesbians and Gay Men: Correlates and Gender Differences. In Journal of Sex Research: Routledge.

Hood, M.V., III, and Seth C. McKee. 2010. What Made Carolina Blue? In-Migration and the 2008 North Carolina Presidential Vote. American Politics Research 38(2):266302.

Hurlbert, Jeanne S. 1989. The Southern Region: A Test of the Hypothesis of Cultural Distinctiveness. Sociological Quarterly 30(2):245-266.

Langer, Gary. 2011. Support for Gay Marriage Reaches a Milestone. In $A B C$ News/ Politics.

Lawrence v. Texas. 2003.

Lax, Jeffrey R., and Justin H. Phillips. 2009. Gay Rights in the States: Public Opinion and Policy Responsiveness. American Political Science Review 103(3):367-386.

Lewis, Gregory B. 1999. Public Opinion and State Sodomy Laws. In American Political Science Association annual meeting. Atlanta.

Lewis, Gregory B. 2001. Public Opinion and State Gay Rights Laws In American Political Science Association annual meeting. San Francisco.

Lewis, Gregory B. 2003. Black-White Differences in Attitudes toward Homosexuality and Gay Rights. Public Opinion Quarterly 67(1):59-78.

Lewis, Gregory B. 2003. Contentious and Consensus Gay Rights Issues: Public Opinion and State Laws on Discrimination and Same-Sex Marriage. In Association for Public Policy Analysis and Management. Washington, DC.

Lewis, Gregory B. 2010. Changing Attitudes toward Same-Sex Marriage. In American Political Science Association. Washington, DC.

Lewis, Gregory B., and Jason Thomas Edwards. 2011. The Role of Cohort Replacement in Rising Support for Lesbian and Gay Rights. In Midwest Political Science Association annual meeting, Chicago. 
Lewis, Gregory B., and Charles W. Gossett. 2008. Changing Public Opinion on SameSex Marriage: The Case of California. Politics and Policy 36(1):4-30.

Lewis, Gregory B., and Seong Soo Oh. 2008. Public Opinion and State Action on SameSex Marriage. State and Local Government Review 40(1):42-53.

Lupia, Arthur, Yanna Krupnikov, Adam Seth Levine, Spencer Piston, and Alexander Von Hagen-Jamar. 2010. Why State Constitutions Differ in their Treatment of SameSex Marriage. Journal of Politics 72(4):1222-1235.

McDonald, Ian. 2010. Migration and Sorting in the American Electorate: Evidence From the 2006 Cooperative Congressional Election Study. American Politics Research 39(3):512-533.

Middleton, Russell. 1976. Regional Differences in Prejudice. American Sociological Review 41(1):94-117.

Moore, Laura M., and Seth Ovadia. 2006. Accounting for Spatial Variation in Tolerance: The effects of Education and Religion. Social Forces 84(4):2205-2222.

Moore, Laura M., and Reeve Vanneman. 2003. Context Matters: Effects of the Proportion of Fundamentalists on Gender Attitudes. Social Forces 82(1):115-139.

National Gay and Lesbian Task Force. 2010. State Laws Prohibiting Recognition of Same-Sex Relationships, June 30, 2009 [cited July 17, 2010]. Available from http://www.thetaskforce.org/downloads/reports/issue_maps/samesex_relationships 7 09.pdf.

National Gay and Lesbian Task Force. 2010. Relationship Recognition for Same-Sex Couples in the U.S. 2011. Available from http://www.thetaskforce.org/downloads/ reports/issue maps/rel_recog_6_28_11_color.pdf.

National Gay and Lesbian Task Force. 2011. State Nondiscrimination Laws in the U.S. 2011 [cited January 2 2011]. Available from http://www.thetaskforce.org/downloads/reports/issue maps/non discrimination 611 color.pdf.

Newport, Frank. 2011. For the First Time, Majority of Americans Favor Legal Gay Marriage. In Gallup.

Nunn, Clyde Z., Harry J. Crockett, and J. Allen Williams. 1978. Tolerance for Nonconformity. San Francisco: Jossey-Bass.

Ohlander, Julianne, Jeanne Batalova, and Judith Treas. 2005. Explaining Educational Influences on Attitudes toward Homosexual Relations. Social Science Research 34(4):781-799.

Pew Research Center for the People and the Press. 2012. 59\% to 33\%-Views on Social Issues by Generation, January 29, 20122011 [cited January 29, 2012]. Available from http://pewresearch.org/databank/dailynumber/?NumberID=1364.

Robinson, Tony, and Stephen Noriega. 2010. Voter Migration as a Source of Electoral Change in the Rocky Mountain West. Political Geography 29(1):28-39.

Royston, Patrick. 2005. Multiple Imputation of Missing Values: Update. Stata Journal 5(2):1-14.

Sherkat, Darren E. 2011. Support for and Opposition to Same Sex Marriage: 1988-2010. In Iranianredneck's Weblog.

Silver, Nate. 2010. Opinion on Same-Sex Marriage Appears to Shift at Accelerated Pace. In FiveThirtyEight: Politics Done Right.

Stouffer, Samuel A. 1955. Communism, Conformity, and Civil Liberties. New York: Doubleday.

Sullivan, Andrew. 2010. Support for Marriage Equality Accelerating? The Daily Dish/ The Atlantic, August 12.

Tuch, Steven A. 1987. Urbanism, Region, and Tolerance Revisited: The Case of Racial Prejudice. American Sociological Review 52(4):504-510. 
Valentino, Nicholas A., and David O. Sears. 2005. Old Times There Are Not Forgotten: Race and Partisan Realignment in the Contemporary South. American Journal of Political Science 49(3):672-688.

Wilcox, Clyde, and Robin Wolpert. 2000. Gay Rights in the Public Sphere: Public Opinion on Gay and Lesbian Equality. In The Politics of Gay Rights, eds. C.A. Rimmerman, K.D. Wald, and C. Wilcox. Chicago: University of Chicago Press.

Wooldridge, Jeffrey M. 2009. Introductory Econometrics: A Modern Approach, 4th ed. Mason, OH: South Western Cengage Learning. 